\title{
EFFECT OF GOVERNMENT SUBSIDIZATION ON CHINESE INDUSTRIAL FIRMS' TECHNOLOGICAL INNOVATION EFFICIENCY: A STOCHASTIC FRONTIER ANALYSIS
}

\author{
Qi HUANG ${ }^{1}$, Marshall S. JIANG ${ }^{2}$, Jianjun MIAO $^{3}$ \\ ${ }^{1,3}$ College of Economics and Management, Nanjing University of Aeronautics \\ and Astronautics, 29 Jiangjun Rd., Nanjing, China 211106 \\ ${ }^{2}$ Goodman School of Business, Brock University, 500 Glenridge Ave., \\ St. Catharines, ON L2S 3A1, Canada \\ E-mail: ${ }^{1} 175693638 @ q q . c o m ;{ }^{2}$ mjiang@brocku.ca (corresponding author); \\ 3miao@nuaa.edu.cn
}

Received 29 January 2015; accepted 09 June 2015

\begin{abstract}
This study aims to gain a better understanding of how effective government subsidization is in helping foster firms' innovation. Drawing on the exploration/exploitation perspective and based on data collected from Statistical Yearbook on Science and Technology Activities of Industrial Enterprises, we look into the relationship between government subsidization and Chinese firms' innovation efficiency by applying a stochastic frontier analysis. The results show that when government subsidies are provided in small scale, firms' innovation efficiency decreases; only when government subsidies increase to a certain scale, does firms' innovation efficiency start to increase. We suggest that government subsidization would generate better innovation performance should it concentrate on a smaller number of firms at one time. As existing research is still inconclusive regarding the relationship between government subsidization and firms' technological innovation output, we shed light on the issue by revealing a "U-shaped" relationship between the two.
\end{abstract}

Keywords: government subsidization, innovation efficiency, technological innovation, stochastic frontier analysis, complementary effect, crowding-out effect.

JEL Classification: M10, O32, O38.

\section{Introduction}

Technological innovation (hereafter, innovation) is the core driver for economic development. Government subsidization is a policy commonly used to enhance firms' innovation activities. There is a belief that government subsidization has a positive impact on firms' innovation output; however, research on this issue has not led to a consistent conclusion about the relationship between government subsidization and firms' innovation output. One stream of research maintains that government subsidization have a positive impact on firms' innovation capabilities (e.g., Clausen 2009; Czarnitzki, Licht 2006; Kleer 2010; Lee 2011; Wang 2011), while a second stream claims that govern- 
ment subsidization has no or a negative impact on firms' innovation output (e.g., Cannone, Ughetto 2014; Feng et al. 2011; Gorg, Strobl 2007; Hu 2001; Xiao et al. 2013). As such, there is a need to solve this puzzle.

We argue that these diverse findings are caused by a measurement problem. The relationship between innovation output and input is measured with the absolute amount of the two values by the existent research. Innovation output usually refers to the creation of new products and new processes (Coombs et al. 1996), though sometimes are measured by the number of patents (Brouwer, Kleinknecht 1999). Innovation input includes mostly R\&D investment and sometimes the acquisition of external technologies (Tang 2006). In this study, we simplify the innovation output as the creation of new products since new processes can be generally termed as new products, and innovation input as R\&D investment because the purchase of external technologies can be considered as the expenditure on R\&D. Innovation output can result from multiple sources of financial input, which can come from the government subsidies, from the firm's own investment, from a bank's loan, or from a venture capital. It may happen that the government subsidy stays at the same level while other sources of input decrease, which may result in a decrease in innovation output. In this case, a negative relationship can occur between government subsidization and firms' innovation output, which might not reflect the reality - that it is the decrease of other sources of input that has caused the output decrease. Hence, by only looking at government subsidies, it is possible to miss the whole picture of the causes of innovation output.

As a remedy, we will look at the issue from an angle that emphasizes innovation efficiency. Innovation efficiency refers to the ratio of innovation output over total input, that is to say, all sources of input, including government subsidies. Innovation efficiency is more comprehensive in reflecting innovation reality. Innovation efficiency increases can result from a smaller decrease of innovation output but a larger decrease of total input, or from a larger increase of output paired with a smaller increase of total input. With many countries facing financial crisis and subsequently economic downturn, it is very common that governments reduce their subsidies. Yet, firms are still anticipated to increase their innovation output given limited financial aid. Innovation output increases can happen even when government subsidies decrease, which occurs when there is successful management innovation (Birkinshaw et al. 2008). When the absolute innovation output value decreases despite government subsidization increases, innovation efficiency might still increase if there are greater decreases in other sources of input. As innovation efficiency takes into consideration all the sources of input, the relationship between a single source of input and innovation efficiency will reveal the true contribution of the single source.

This study attempts to answer the following questions. First, how does government subsidization affect firms' innovation efficiency? Second, what is the theoretical explanation underlying this effect? We first offer a brief literature review, followed by theory and hypothesis development. We report the empirical method and the results in the third section and provide discussion and conclusions in the final section. 


\section{Literature review}

The relationship between government subsidization and firms' innovation output has been extensively studied but the results have been inconclusive. Some research has reported a positive relationship, meaning government subsidization improves firms' innovation output. Lee (2011) found that government subsidization to firms' R\&D activities, as a complement to firms' own R\&D investment, significantly improve firms' innovation capability, particularly in firms that have a substantial room for upgrading their technological capabilities in high competitive industries. Kleer's study (2010) found that government subsidization in terms of financial support lowers the costs and risks of firms' investment in innovation, thereby attracting more investment in innovation from other sources and eventually leading to more innovation output. In addition, Czarnitzki and Licht (2006) established empirically a positive relationship between government subsidization and firms' innovation output, namely, that government subsidization significantly raises the percentage of successful attainment of patent registration. Clausen (2009) categorized government subsidization as a form of research subsidization and product development subsidization and found that while research subsidization has a positive impact on firms' innovation output, product development subsidization reduces the firms' input in innovation. Nonetheless, government subsidization complements rather than crowds out firms' own investment in innovation. Based on the data from Chinese manufacturing firms, Wang (2011) found that there is a difference of output elasticity associated with government subsidization to R\&D activities in different industries; government subsidization creates more innovative output in small-sized but highly promising high-tech enterprises.

The second group of reports maintains that government subsidization does not enhance firms' innovation output, and sometimes even constrains firms' innovation activities, which eventually leads to a negative effect on innovation. Cannone and Ughetto (2014) found that the subsidized firms show an increase in indebtedness, while there is no evidence of any impact on firms' profitability. Hu (2001) did not find a significant relationship between government subsidization and subsidized firms' improvement in productivity in Chinese industries, while Gorg and Strobl (2007) found that government subsidization increases the demand for resources used in R\&D activities. With an inelastic supply of R\&D-related materials in the short term, government subsidization will increase the costs of firms' innovation activities, thereby creating a cancel-off effect on firms' innovation. Feng et al. (2011) also found a negative though weak relationship between government subsidization and firms' technological efficiency in medium-tolarge-sized industrial firms; in fact, government subsidization has significantly negative effect on the scale efficiency of innovation activities in those firms.

The above brief review shows that the effect of government subsidization on firm's innovation output is mixed. This mixed result might be due to an incomplete examination of all the sources of input. There is surely a causal relationship between innovation input and output. As there are multiple sources of input (e.g., government subsidy, internal investment, private input from foreign or other organizations), examining the relation- 
ship between innovation output and a single source of input may lead to a distorted result. It is necessary to look into innovation efficiency, which takes into consideration both output and the total input, in order to correct the previous limited views that only look into the relationship between a single input and the absolute value of the output.

\section{Theory and hypothesis}

To compete effectively in markets, organizations must find a balance between two types of innovation activities - exploratory innovation and exploitative innovation (March 1991; Mueller et al. 2013). Exploratory innovation includes search, research, discovery, experimentation, and risk-taking (March 1991; McGrath 2001). It primarily involves challenging and departing from the existing knowledge and technologies. Exploitative innovation usually entails making improvements to existing knowledge, skills, and processes (Levinthal, March 1993). It mainly involves development, refinement, increasing efficiency, and fine-tuning production (Levinthal, March 1993).

The important differences between the two types of innovation lie in the levels of outcome uncertainty and the temporal distance between the locus of learning and the realization of returns (March 1991). Exploratory innovation is highly uncertain because it involves approaching territories of knowledge which are unknown and unpredictable; thus, the failure rate for exploratory innovation is much higher (Garcia et al. 2003). In contrast, the uncertainty level for exploitative innovation is much lower because the activities involve building on existing knowledge in order to improve some part or sections of a technology or product. Exploratory innovation targets long-term outcomes as research tasks are on a larger scale and progress slowly as exploratory innovation is "experimental" in manner and cannot rely completely on existing and familiar knowledge. Exploitative innovation, on the other hand, has a shorter and more specific schedule, and its outcomes are more predictable. Exploitative innovation aims at commercializing improved technology to meet the demands of existing markets (Benner, Tushman 2003). As exploitative innovation improves existing knowledge, the knowledge base of the firm must be well-established. Some exploratory activities should have already been conducted in firms in order that exploitation can be done on the existing knowledge base. In firms' research and development activities, research activities are exploratory while development are more exploitative (Garcia et al. 2003), thus, research activities need to be conducted before development activities can begin.

Exploratory innovation and exploitative innovation are not exclusive and are generally carried out simultaneously. As firms' resources are limited, there is a balance in allocating resources between the two types of innovation. Exploratory innovation is inherently risky and involves a longer term investment but provides firms with a long-term competitive advantage; while exploitative innovation, though short-term oriented, creates cash-generating opportunities which not only stabilize the competitive position of firms in the current markets but also supports long-term exploratory innovation through such necessary resources as cash. Neither of the two types of innovation can afford to be ignored. However, when constrained by limited resources and the high expectation of the funding sources, firms are more likely to focus on exploitative innovation over 
exploratory innovation as exploitative innovation is necessary for the short-term goal of survival. When they are endowed with slack resources and the sources of funding have soft but long-term expectations, firms will do more exploratory innovation in order to obtain long-term competitive sustainability (Garcia et al. 2003).

When allocating resources in the two types of innovation activities, the source of the resources can affect firms' decision making. As the sources of funding impose different levels of pressure on firms, firms have different tactics for responding to those institutional pressures and expectations (Oliver 1991). Compared with internal funding or funding from banks, government subsidization to firms' R\&D activities places "soft budget constraints" and exerts relatively low pressure on firms (Buckley et al. 2007). Funds with tight budget constraints tend to induce firms to focus more on short-term returns, while funds with soft budget constraints allow firms to invest in riskier and longer-term oriented objectives. As a result, firms are more likely to use government subsidization in their exploratory innovation activities.

The innovation efficiency perspective takes into consideration the cost and time invested in innovation projects (Wheelwright, Clark 1992). Innovation efficiency is improved when more innovation outputs are generated for the same costs and time or when the same outputs are generated with lower costs and less time. Innovation efficiency is thus the ratio of outputs over inputs. Previous literature has examined innovation inputs or outputs separately in order to measure the effects of technological innovation on firm performance with mixed results (Cruz-Cázaresa et al. 2011). Innovation is a complex process and thus should be evaluated as such (Tidd, Bessant 2009). Using efficiency to examine firms' innovation performance captures innovation outcome better as efficiency avoids the skewed perspective created by considering inputs and outputs separately, a perspective that ignores the process of innovation (Cruz-Cázaresa et al. 2011). To some extent, innovation efficiency reveals firms' management capability, namely, their attitude towards using available inputs in the process of maximizing outputs (Barney, Hesterly 2014).

Regarding how government subsidization leads to firms' innovation efficiency, we predict that it is not the linear effect that previous studies have attempted to prove. As exploratory innovation requires a longer-term schedule and poses higher risk, and as government subsidization places relatively soft budget constraints, firms are more likely to use government subsidization (rather than internally raised funds or bank loans) for exploratory innovation activities. For Chinese firms, government subsidies encourage firms' decisions to freeze their internal capital input in order to receive subsequent government subsidies, thereby creating a crowding-out effect (Xiao et al. 2013) and leading to a situation in which a firm's total input in R\&D activities might become lower after receiving a government subsidy.

When government subsidization occurs on a small scale and firms use these subsidies in their exploratory innovation activities, innovation outputs from exploratory innovation activities may not be produced quickly because the new knowledge has to be created through exploration before exploitation can happen. It is impossible for com- 
mercialization based on new knowledge to occur while the new knowledge is still being created. Continuous inputs do not guarantee outputs from exploratory innovation activities. Though exploratory scientific research enhances understanding in a special knowledge domain, it may not have an immediate effect on new product output. Moreover, exploratory research is known to be risky and has a high failure rate particularly with insufficient and discontinuous funding. In this case, firms' innovation efficiency may decline when the inputs are on a small scale. We argue that when firms only use government subsidization for exploratory innovation activities and the subsidization is in small scale, firms' performance in terms of innovation efficiency declines. In contrast, when government subsidization comes in a large scale, sufficient enough to complete stages of exploratory innovation, firms will use the rest of the fund in combination with their internally raised funds for exploitative innovation, launching new products, thereby generating noticeable outputs. As a result, innovation efficiency starts to increase. Taken together, the above discussions lead to the following hypothesis.

Hypothesis: There is a U-shaped relationship between government subsidization and firms' innovation efficiency such that firms' innovation efficiency declines first and then increases with the increase of government subsidization.

\section{Methodology}

\subsection{Models}

The stochastic frontier analysis (SFA) model is used in the substantial literature of studies of production, cost, revenue, and profit, and was developed originally by Aigner et al. (1977). The stochastic frontier model is:

$$
y=f(x, \alpha)+v-u,
$$

where $y$ is the observed outcome (goal attainment); $\alpha$ is the to-be-estimated coefficient; $f(x, \alpha)=\alpha_{0}+\sum \alpha_{i} x_{i}$ is the function of output from input $x$, which determines part of the frontier; $v$ is the stochastic part; $f(x, \alpha)+v$ is the optimal frontier goal; and $u$ represents "inefficiency," which is a positive, random variable, and a measure of percentage by which the particular observation fails to achieve the frontier, the ideal production rate.

A strictly orthodox interpretation embedded in a Cobb-Douglas production model will lead to the following model (Greene 2002):

$$
\ln y=\alpha_{0}+\sum \alpha_{i} \ln x_{i}+v-u
$$

or

$$
y=f(x, \alpha) \exp (v-u) .
$$

Specifically in this study, the form is:

$$
y_{i(t+1)}=f\left(x_{i t}, \alpha\right) \exp \left(v_{i t}-u_{i t}\right),
$$

where $y_{i(t+1)}$ is the innovation output, $i$ is the province in which the firms in question are located; $t+1$ refers to time (a year ahead of inputs), taking into consideration the 
delayed effect of inputs on the output so that $y$ is forwarded to the year of $t+1 ; x_{i t}$ is the input vector; $v_{i t}-u_{i t}$ is the error; and $v$ is the stochastic part and presents a symmetric disturbance: $v \sim N\left[0, \sigma_{v}^{2}\right] . u$ is independent from $v$ and has a truncated distribution above zero: $u \sim N\left[0, \sigma_{u}^{2}\right]$ (Aigner et al. 1977).

When choosing a specific production model for our study, the translog model is more appropriate than the Cobb-Douglas model. The Cobb-Douglas production model assumes that technologies are neutral and that the output elasticities of the input factors are constant, while the translog model is more relaxed regarding these assumptions (van Garderen et al. 2000). When using panel data, it is impossible to know beforehand whether the assumed conditions can be met. Therefore, the translog model is adopted here:

$$
\left\{\begin{array}{l}
\ln Y_{i(t+1)}=\alpha_{0}+\alpha_{1} \ln K_{i t}+\alpha_{2} \ln L_{i t}+\frac{1}{2} \alpha_{3}\left(\ln K_{i t}\right)^{2}+\frac{1}{2} \alpha_{4}\left(\ln L_{i t}\right)^{2}+\alpha_{5} \ln K_{i t} \times \ln L_{i t}+v_{i t}-u_{i t} \\
\sigma^{2}=\sigma_{v}^{2}+\sigma_{u}^{2} \\
\lambda=\frac{\sigma_{u}^{2}}{\sigma^{2}}
\end{array}\right.
$$

where $K$ refers to capital input, which includes capital input from all sources, and $L$ refers to labor input. If $\lambda$ is close to 0 , then there is no inefficiency effect.

One important extension of the SFA model is that production efficiency can be measured by the ratio between the total output $Y$ and the optimal frontier (Aigner et al. 1977). As a result, the innovation efficiency in this study is measured by the ratio:

$$
T E_{i t}=\frac{f\left(x_{i t}, \theta\right) \exp \left(v_{i t}-u_{i t}\right)}{f\left(x_{i t}, \theta\right) \exp \left(v_{i t}\right)},
$$

where $T E$ stands for technological efficiency, with a value between 0 and 1 . In order to explain the factors affecting technological inefficiency, we adopt Battese and Coelli's (1995) technological inefficiency function:

$$
u_{i t}=\beta_{0}+\beta_{1} \text { Gov }_{i t}+\beta_{2} G o v_{i t}^{2}+\beta Z_{i t}+w_{i t},
$$

in which Gov ${ }_{i t}$ refers to government subsidization, $Z_{i t}$ refers to the rest of the factors affecting technological innovation efficiency, including infrastructure development level, labor quality, and market openness according to previous studies (Cooke et al. 1998; Crepon et al. 1998; Dahlander, Gann 2010); and $w_{i t}$ is the random error. As $u>=0$, the interpretation of the sign of these coefficients will reflect their effect on inefficiency.

\subsection{Data and variables}

The panel data come from "Statistical Yearbook on Science and Technology Activities of Industrial Enterprises" and "China Statistical Yearbook" published between 2006 and 2013. We included 29 provinces without Tibet and Hainan because there are too many missing data from the two provinces. 
$Y_{i(t+1)}$, Innovation Output is measured by the total sales of new products in $i$ province in year $t+1$, taking into consideration a delayed effect of the inputs on the output. Particularly, the new product sales of a certain year are adjusted by the industrial outof-factory price index of that year.

$K_{i t}$, Capital Input: Drawing on Costa et al. (1987), the capital input of R\&D can be calculated by using a perpetual inventory method:

$$
K_{i t}=(1-\alpha) K_{i(t-1)}+I_{i t},
$$

$K_{i t}$ refers to the capital input of $i$ province in year $t$; and $K_{i(t-1)}$ is the capital input of $i$ province in year $t-1$. The capital input of a certain time is the depreciated stock of previous years' input plus the current year's intramural R\&D expenditure, $I_{i t}$, which should be adjusted based on the price index of that year. $L_{i p}$ Labor input refers to the full-time equivalent of R\&D personnel in $i$ province in year $t$, a variable with a standardized value in the database. This variable is a quantified description of the total manpower and time consumption in innovation activities in organizations. Gov ${ }_{i p}$ Government subsidy is the main factor in this study. The operationalization of this variable is to use a ratio between the amount of capital subsidized by all levels of government and the amount of the total input in firms' R\&D expenses in province $i$ in year $t$. Infrastructure Development is represented by a proxy index which uses the total service value of telecommunication divided by the GDP of that province (Wang et al. 2012). The service value of telecommunication is critical to innovation activities because innovation activities rely heavily on the exchange of information and personnel coordination. Labor Quality is measured by the number of currently registered students in the universities and colleges out of every 100,000 people in that province as the majority of the graduated students will work in the organizations of that province ( Zhu et al. 2012). Market Openness is related to the exchange of goods with international market and thus is measured by the ratio of the total value of the import and export and the GDP of that province.

\subsection{Results}

Table 1 presents the variable statistics. Table 2 reports the results of the Stochastic Frontier Analysis, corresponding to function (5), in which we have four models. In order to see whether there are differences in terms of innovation efficiency among areas with different levels of economic development, we divide the 29 provinces into three areas - the East, the Middle, and the West areas. Model 1 reports the results of all the provinces; Model 2 reports those of the East area, Model 3 the Middle area, and Model 4 the West area. As previously mentioned, if $\lambda$ is close to 0 , there is no inefficiency issue. In all four models, $\lambda$ is greater than 0.5 , which indicates that inefficiency exists. In the meantime, the $p$ values in all the models are significant, which indicates that all the models fit well.

Table 3 presents the results of the innovation inefficiency models corresponding to function (7). In all four models, the coefficients of Government Subsidization (Gov) are positive and statistically significant, while the coefficients of Gov square are negative and statistically significant, which suggests an inverted U-shaped relationship between government subsidization and innovation inefficiency, or a U-shaped one between gov- 
Table 1. Descriptive statistics

\begin{tabular}{cccccc}
\hline Variable & Unit & Mean & Minimum & Maximum & Standard deviation \\
\hline$Y$ & 10000 yuan & 22949371.477 & 65755.443 & 132541398.834 & 23975958.817 \\
\hline$K$ & 10000 yuan & 3826908.901 & 22912.806 & 22347187.331 & 3759719.312 \\
\hline$L$ & man-year & 49638.300 & 529.000 & 346260.000 & 49396.400 \\
\hline Gov & $\%$ & 0.102 & 0.022 & 0.926 & 0.110 \\
\hline $\begin{array}{c}\text { Infrastructure } \\
\text { Development }\end{array}$ & $\%$ & 0.076 & 0.016 & 0.119 & 0.019 \\
\hline $\begin{array}{c}\text { Labor Quality } \\
\text { Market }\end{array}$ & Person & 2357.379 & 1043.000 & 6410.000 & 1022.767 \\
\hline \begin{tabular}{c} 
Openness \\
\hline
\end{tabular} & 0.310 & 0.036 & 1.548 & 0.384 \\
\hline
\end{tabular}

Table 2. Results of the stochastic frontier analysis

\begin{tabular}{ccccc}
\hline Variable & Model 1 & Model 2 & Model 3 & Model 4 \\
\hline Constant & $6.750^{*}$ & -2.137 & -3.099 & 1.139 \\
& $(-1.611)$ & $(-1.213)$ & $(-0.735)$ & $(1.329)$ \\
\hline $\ln K$ & $-3.109^{* *}$ & 0.260 & -0.548 & -5.583 \\
& $(-2.619)$ & $(0.987)$ & $(-0.903)$ & $(-1.142)$ \\
\hline $\ln L$ & $1.805^{*}$ & $3.014^{* * *}$ & $1.078^{* * *}$ & 0.978 \\
& $(1.730)$ & $(3.081)$ & $(5.003)$ & $(1.307)$ \\
\hline$(\ln K)^{2}$ & $0.134^{*}$ & $0.408^{* *}$ & $0.390^{*}$ & $0.271^{*}$ \\
& $(1.718)$ & $(2.763)$ & $(1.743)$ & $(1.694)$ \\
\hline$(\ln L)^{2}$ & 0.229 & 0.195 & 0.317 & $0.732^{*}$ \\
& $(0.383)$ & $(0.596)$ & $(0.629)$ & $(1.676)$ \\
\hline $\ln K \times \ln L$ & -0.102 & 0.794 & $-0.589^{* *}$ & $-0.539^{*}$ \\
& $(-1.561)$ & $(-0.747)$ & $(-2.023)$ & $(-1.604)$ \\
\hline$\sigma^{2}$ & $0.582^{* * *}$ & $0.478^{* * *}$ & $0.236^{* * *}$ & $0.513^{* * *}$ \\
& $(5.407)$ & $(5.902)$ & $(7.006)$ & $(5.088)$ \\
\hline 1 & $0.705^{* * *}$ & $0.648^{* * *}$ & $0.595^{* *}$ & $0.649^{*}$ \\
& $(3.784)$ & $(3.009)$ & $(2.803)$ & $(1.993)$ \\
\hline Log-likelihood & -121.319 & -113.541 & -130.632 & -125.769 \\
\hline
\end{tabular}

Notes: $\mathrm{t}$-values are in parentheses. ${ }^{* * *}$ p-value $\leq 0.01,{ }^{* *}$ p-value $\leq 0.05,{ }^{*}$-value $\leq 0.1$.

ernment subsidization and innovation efficiency. Thus, our hypothesis is supported that the effect of government subsidization first reduces and then increases innovation efficiency (see Fig. 1). The effect of the Infrastructure Development level is only statistically significant in Model 4 (the West area). The negative sign of its coefficient indicates that it helps reduce inefficiency. We speculate that the Infrastructure Development level does not have a significant effect on the East and Middle areas because the infrastructure in the two areas has developed long before the West so that its marginal effect declines. 
Table 3. Results of the innovation inefficiency models

\begin{tabular}{ccccc}
\hline Variable & Model 1 & Model 2 & Model 3 & Model 4 \\
\hline Constant & $1.249^{* *}$ & $1.163^{* * *}$ & 0.874 & $0.236^{*}$ \\
& $(2.654)$ & $(5.520)$ & $(0.914)$ & $(1.738)$ \\
\hline Gov & $4.919^{* * *}$ & $4.108^{* * *}$ & $3.873^{* * *}$ & $3.625^{* * *}$ \\
& $(3.943)$ & $(3.628)$ & $(5.129)$ & $(6.277)$ \\
\hline Gov $^{2}$ & $-6.275^{*}$ & $-7.006^{* *}$ & $-3.670^{* * *}$ & $-2.931^{* *}$ \\
& $(-1.789)$ & $(-2.744)$ & $(-4.472)$ & $(-2.516)$ \\
\hline Infrastructure & -2.993 & -1.679 & 5.628 & $-8.985^{* *}$ \\
Development & $(-0.843)$ & $(-1.394)$ & $(0.721)$ & $(-2.420)$ \\
\hline Labor Quality & $-0.025^{* * *}$ & $-0.009^{* *}$ & $-0.013^{* *}$ & $-0.022^{* * *}$ \\
& $(-7.206)$ & $(-2.628)$ & $(2.005)$ & $(3.409)$ \\
\hline Market Openness & $-1.276^{* * *}$ & $-0.963^{*}$ & $-3.729^{* * *}$ & $-5.281^{* * *}$ \\
& $(-8.928)$ & $(-1.740)$ & $(-9.005)$ & $(-13.373)$ \\
\hline
\end{tabular}

Notes: $\mathrm{t}$-values are in parentheses. ${ }^{* * *}$ p-value $\leq 0.01,{ }^{* *}$ p-value $\leq 0.05,{ }^{*}$-value $\leq 0.1$.

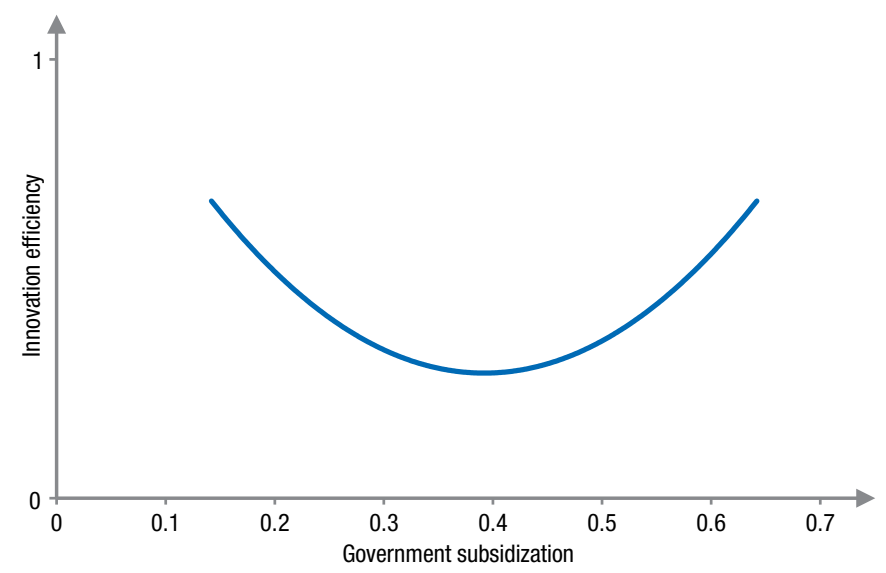

Fig. 1. U-shaped relationship between government subsidization and innovation efficiency

Market Openness helps reduce inefficiency because market openness motivates learning and induces firms to increase investment in innovation. However, Market Openness is marginally significant in the East area while very significant in the other two areas. The market opened much earlier in the East than the other regions so that may explain why the positive effect of market openness is less significant in the East area. Labor Quality is significant in all the three regions because it is the main factor contributing to innovation such that its effect is comparable in all areas.

\section{Conclusions}

Through testing the stochastic frontier to see firms' innovation efficiency as a result of government subsidization, we found that there is a U-shaped relationship between the two; therefore, we make the following contributions. First, this finding resolves the is- 
sue of inconclusiveness in the literature regarding the relationship between innovation output and government subsidization. When government subsidies are offered to firms on a small scale, firms' innovation efficiency declines because firms use the subsidies in exploratory innovation projects which do not create immediate performance, as reflected in those findings of Czarnitzki and Hussinger (2004), Lee (2011), Kleer (2010), etc.; whereas when government subsidies are provided on a large scale, firms' innovation efficiency starts to increase as exploitative innovation benefits directly from exploratory innovation and generates new products, thereby increasing innovation performance, as shown in the findings of Cannone and Ughetto (2014), Feng et al. (2011), Gorg and Strobl (2007), etc. It is also confirmed by Janz et al. (2004) that German government focuses its subsidies on fewer but large companies in order to reach greater innovation output, a phenomenon supporting the U-shape relationship. Second, by categorizing innovation into exploratory and exploitative, we argue that the major differences between the two types of innovation lie in the degree of riskiness and the sustainability of competitiveness created from innovation. Consequentially, firms make their investment decisions for the two types of innovation based on the characteristics of the sources of funds. Government subsidies offer soft budget constraints and impose less pressure on firms, such that firms are more likely use the subsidies in exploratory innovation activities. Although there is an extensive literature on how institutions influence firms' decisions regarding innovations, we add to the literature a new finding that government subsidization encourages more exploratory innovation in firms. Third, methodologically, we use SFA to solve the conundrum of how government subsidization affects firms' innovation output and argue that using firms' innovation efficiency is a better way to measuring firm performance, which departs from the previous method of measuring separately inputs and outputs of innovation activities.

We address some implications for policy making. As the relationship between government subsidization and firms' innovation efficiency is a U-shaped one, we hope to reduce the effect on the downward slope and enlarge the effect on the upward curve. In order to avoid the downward slope, it is optimal to skip the "small scale" threshold of government subsidies. A good solution is for governments to increase subsidies to a larger scale. Yet as government subsidization is a budgeted resource and cannot be enlarged arbitrarily, it is practical to concentrate subsidies on a selected smaller number of firms each year so that those firms can receive enough funding to pass the "small scale" threshold. The disadvantage of this approach is that other firms that also need government subsidies may have to wait longer for their turn. As shown in our data analysis, infrastructure development, market openness, and labor quality are positive factors in their effects on innovation efficiency, particularly for the west area of China where innovation efficiency is relatively low. If infrastructure development and labor quality need a longer term to change, market openness can be changed by providing incentives through favorable policies such as tax returns with a particularly large weight emphasizing the west area. In order for the west area to catch up with the middle and east areas in innovation efficiency, a policy that can attract high quality human resources to the west area should also be implemented. 
Our research has some limitations, some of which can serve as directions for future research. First, our study is based on data collected from published sources at an aggregate provincial level rather than at a firm level, such that we do not have information on individual firms, which are the focal centers of efficiency studies. Future research should collect firm level data so that more robust results can be revealed. Second, we argue that exploratory innovation is riskier than exploitative innovation, and that firms would use funds with soft-budget constraints on riskier research projects. This is still a hypothesis, though it is logical. Future research can empirically test this hypothesis using firm level survey data. Finally, innovation efficiency is measured by the ratio of output and input. As output refers to the sale of new products, it mainly reflects the output of exploitative innovation. Exploratory innovation output should include new theories and new laws, which are difficult to quantify. The challenge for future research is to find a better measure that can reflect exploratory innovation output so that stochastic frontier analysis can be more accurate in testing the special area of innovation.

\section{References}

Aigner, D.; Lovell, C. A. K.; Schmidt, P. 1977. Formulation and estimation of stochastic frontier production function models, Journal of Econometrics 6(1): 21-37.

http://dx.doi.org/10.1016/0304-4076(77)90052-5

Barney, J.; Hesterly, W. 2014. Strategic management and competitive advantage: concepts. New Jersey: Pearson.

Battese, G. E.; Coelli, T. J. 1995. A model for technical inefficiency effects in a stochastic frontier production function for panel data, Empirical Economics 20(2): 325-332.

http://dx.doi.org/10.1007/BF01205442

Benner, M. J.; Tushman, M. L. 2003. Exploitation, exploration, and process management: the productivity dilemma revisited, Academy of Management Review 28(2): 238-256.

Birkinshaw, J.; Hamel, G.; Mol, M. J. 2008. Management innovation, Academy of Management Review 33(4): 825-845. http://dx.doi.org/10.5465/AMR.2008.34421969

Brouwer, E.; Kleinknecht, A. 1999. Innovative output, and a firm's propensity to patent: an exploration of CIS micro data, Research Policy 28(6): 615-624.

http://dx.doi.org/10.1016/S0048-7333(99)00003-7

Buckley, P. J.; Clegg, L. J.; Wang, C. 2007. Is the relationship between inward FDI and spillover effects linear? An empirical examination of the case of China, Journal of International Business Studies 38(3): 447-459. http://dx.doi.org/10.1057/palgrave.jibs.8400274

Cannone, G.; Ughetto, E. 2014. Funding innovation at regional level: an analysis of a public policy intervention in the piedmont region, Regional Studies 48(2): 270-283.

http://dx.doi.org/10.1080/00343404.2011.653338

Clausen, T. H. 2009. Do subsidies have positive impacts on R\&D and innovation activities at the firm level?, Structural Change and Economic Dynamics 20(2): 239-253.

http://dx.doi.org/10.1016/j.strueco.2009.09.004

Cooke, P.; Uranga, M. G.; Etxebarria, G. 1998. Regional systems of innovation: an evolutionary perspective, Environment and Planning A 30: 1563-1584. http://dx.doi.org/10.1068/a301563

Coombs, R.; Narandren, P.; Richards, A. 1996. A literature-based innovation output indicator, Research Policy 25(3): 403-413. http://dx.doi.org/10.1016/0048-7333(95)00842-X 
Costa, J. D. S.; Ellson, R. W.; Martin, R. C. 1987. Public capital, regional output, and development: some empirical evidence, Journal of Regional Science 27(3): 419-437.

http://dx.doi.org/10.1111/j.1467-9787.1987.tb01171.x

Crepon, B.; Duguet, E.; Mairessec, J. 1998. Research, innovation and productivity: an econometric analysis at the firm level, Economics of Innovation and New Technology 7(2): 115-158. http://dx.doi.org/10.1080/10438599800000031

Cruz-Cázaresa, C.; Bayona-Sáezb, C.; García-Marcob, T. 2011. You can’t manage right what you can't measure well: technological innovation efficiency, Research Policy 42(6/7): 1239-1250.

Czarnitzki, D.; Hussinger, K. 2004. The link between R\&D subsidies, R\&D spending and technological performance, Discussion Paper No. 04-056. ZEW.

Czarnitzki, D.; Licht, G. 2006. Additionality of public R\&D grants in a transition economy, Economics of Transition 14(1): 101-131. http://dx.doi.org/10.1111/j.1468-0351.2006.00236.x

Dahlander, L.; Gann, D. M. 2010. How open is innovation?, Research Policy 39(6): 699-709. http://dx.doi.org/10.1016/j.respol.2010.01.013

Feng, Z. X.; Wang, Q.; Hou, X. H. 2011. Government investment, degree of marketization and technological innovation efficiency of Chinese industrial enterprises, The Journal of Quantitative \& Technical Economics 4: 3-17.

Garcia, R.; Calantone, R.; Levine, R. 2003. The role of knowledge in resource allocation to exploration versus exploitation in technologically oriented organizations, Decision Science 34: 323-349. http://dx.doi.org/10.1111/1540-5915.02407

Gorg, H.; Strobl, E. 2007. The effect of R\&D subsidies on private R\&D, Economica 74: 215-234. http://dx.doi.org/10.1111/j.1468-0335.2006.00547.x

Greene, W. H. 2002. Econometric analysis. Upper Saddle River, NJ: Prentice Hall.

$\mathrm{Hu}$, A. G. 2001. Ownership, government R\&D, private R\& D, and productivity in Chinese industry, Journal of Comparative Economics 29(1): 136-157. http://dx.doi.org/10.1006/jcec.2000.1704

Janz, N.; Lööf, H.; Peters, B. 2004. Firm level innovation and productivity - is there a common story across countries?, Working paper. S-WoPEc.

Kleer, R. 2010. Government R\&D subsidies as a signal for private investors, Research Policy 39(10): 1361-1374. http://dx.doi.org/10.1016/j.respol.2010.08.001

Lee, C. Y. 2011. The differential effects of public R\&D support on firm R\&D: theory and evidence from multi-country data, Technovation 31(5/6): 256-269.

http://dx.doi.org/10.1016/j.technovation.2011.01.006

Levinthal, D. A.; March, J. G. 1993. The myopia of learning, Strategic Management Journal 14: 95-112. http://dx.doi.org/10.1002/smj.4250141009

March, J. G. 1991. Exploration and exploitation in organizational learning, Organization Science 2(1): 71-87. http://dx.doi.org/10.1287/orsc.2.1.71

McGrath, R. G. 2001. Exploratory learning, innovative capacity, and managerial oversight, Academy of Management Journal 44(1):118-131. http://dx.doi.org/10.2307/3069340

Mueller, V.; Rosenbusch, N.; Bausch, A. 2013. Success patterns of exploratory and exploitative innovation: a meta-analysis of the influence of institutional factors, Journal of Management 39(6): 1606-1636. http://dx.doi.org/10.1177/0149206313484516

Oliver, C. 1991. Strategic responses to institutional processes, Academy of Management Review 16(1): 145-179.

Tang, J. 2006. Competition and innovation behaviour, Research Policy 35(1): 68-82.

http://dx.doi.org/10.1016/j.respol.2005.08.004 
Tidd, J.; Bessant, J. 2009. Managing innovation, integrating technological, market and organizational change. Chichester, England: John Wiley \& Sons Ltd.

van Garderen, K. J.; Lee, K.; Pesaran, M. H. 2000. Cross-sectional aggregation of non-linear models, Journal of Econometrics 95(2): 285-331. http://dx.doi.org/10.1016/S0304-4076(99)00040-8

Wang, C.; Hong, J.; Kafouros, M.; Wright, M. 2012. Exploring the role of government involvement in outward FDI from emerging economies, Journal of International Business Studies 43(7): 655-676. http://dx.doi.org/10.1057/jibs.2012.18

Wang, J. 2011. Comparison on R\&D output elasticity about government and enterprise, The Journal of Quantitative \& Technical Economics 6: 93-106.

Wheelwright, S. C.; Clark, K. B. 1992. Revolutionizing product development-Quantum leaps in speed, efficiency, and quality. New York, NY: The Free Press.

Xiao, D. D.; Zhu, G. L.; Wang, J. 2013. The impact of government S \& T input on the enterprise's $\mathrm{R} \& \mathrm{D}$ expenditure: empirical research based on quantile regression, $R \& D$ Management $3: 25-32$ (in Chinese).

Zhu, C. L.; Shi, P.; An, L. R. 2012. Human capital,its structure and R\&D innovation efficiency based on the test of SFA model, Journal of Engineering Management 26: 58-63.

Qi HUANG is PhD candidate of Management Science and Engineering at School of Economics and Management, Nanjing University of Aeronautics and Astronautics. His research focuses on regional economics and industrial economics. He has published on journals such as Systems Engineering, Reform of Economic System, and Science and Technology Management Research.

Marshall S. JIANG is Associate Professor of International Business at Goodman School of Business, Brock University. He received his PhD from York University. His research focuses on international licensing, joint ventures, knowledge transfer, innovation, and entrepreneurship. He has published on journals such as the Journal of International Business Studies, Management International Review, International Marketing Review, and the Journal of International Management.

Jianjun MIAO is Professor of Economics at School of Economics and Management, Nanjing University of Aeronautics and Astronautics. He received his $\mathrm{PhD}$ from Sichuan University. His research focuses on regional economics and industrial economics. He has published on journals such as China Industrial Economics, Industrial Economics Research, and Soft Science. 